University of Rhode Island

DigitalCommons@URI

The Rhode Island Current Conditions Index

Economics

$10-2010$

\title{
Rhode Island Current Conditions Index - October 2010
}

Leonard Lardaro

University of Rhode Island, lardaro@uri.edu

Follow this and additional works at: https://digitalcommons.uri.edu/ricci

Part of the Econometrics Commons

Terms of Use

All rights reserved under copyright.

\section{Recommended Citation}

Lardaro, Leonard, "Rhode Island Current Conditions Index - October 2010" (2010). The Rhode Island Current Conditions Index. Paper 9.

https://digitalcommons.uri.edu/ricci/9

This Article is brought to you for free and open access by the Economics at DigitalCommons@URI. It has been accepted for inclusion in The Rhode Island Current Conditions Index by an authorized administrator of DigitalCommons@URI.For more information, please contact digitalcommons-group@uri.edu. 


\section{EURRENT D Th}
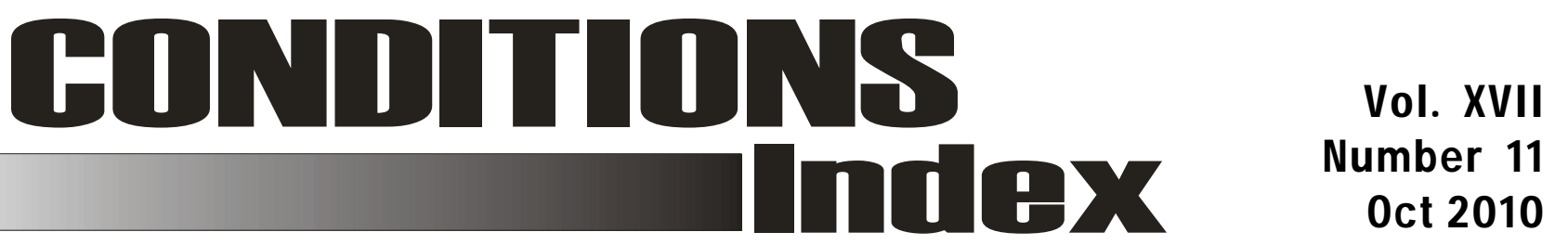

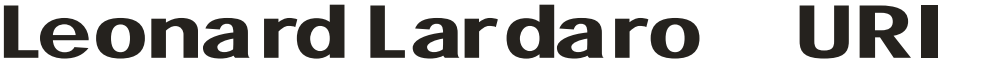

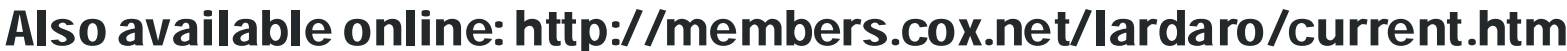

October marked the first real challenge to Rhode Island's economic recovery. After surviving its first test in September, sustaining an expansion reading (of 58) with two of the "foundation" indicators failing to improve, October saw the Current Conditions Index fall to 42, a contraction-range reading. Retail Sales, which failed to improve in September, showed a strong increase in October, rising by 5.6 percent. Its upward trend clearly remains intact at this time. But US Consumer Sentiment, another of the elements of our recent "foundation," failed to improve once again, falling this month by 4.1 percent. To some extent this is not surprising, since it had an extremely difficult "comp" - it rose by 22 percent last October. And, prior to these recent declines, its consecutive improvement streak had been very long. As of now, it does not appear that the trend in this indicator has reversed.

The possibility of trend reversals for several other indicators might be in progress, though. Single-Unit Permits, which reflects new home construction, fell sharply in October, by 28 percent, to an annualized rate of only 615 units. While it is not realistic to assume that levels such as this will persist, its "comps" over the next few months will be difficult to beat. So we will likely see some weakness in this indicator for the next

\begin{tabular}{|l|c|}
\hline \multicolumn{2}{|c|}{ CCI Indicators - \% Change } \\
\hline Government Employment & -0.3 \\
\hline US Consumer Sentiment & -4.1 \\
\hline Single-Unit Permits & -28.1 \\
\hline Retail Sales & 5.6 Y \\
\hline Employment Services J obs & -13.2 \\
\hline Priv. Serv-Prod Employment & -0.8 \\
\hline Total Manufacturing Hours & 2.2 Y \\
\hline Manufacturing Wage & 3.8 Y \\
\hline Labor Force & -0.0 \\
\hline Benefit Exhaustions & -24.8 Y \\
\hline New Claims & 4.9 \\
\hline Unemployment Rate (change) & -0.9 Y \\
\hline \multicolumn{2}{|c|}{ Y = I mproved Value } \\
\hline
\end{tabular}

several months. A similar behavior might also occur for the Labor Force. This indicator has improved for a very long time, but this string of improvements was linked to the need for unemployed persons to be actively seeking employment to qualify for benefits. As increasing numbers of Rhode Islanders exhaust all benefit entitlement, if they stop actively seeking employment, the Labor Force will decline for months to come. Ironically, the flip side of those changes would be substantial improvements in our state's Unemployment
Rate. Much of the recent decline in our jobless rate has been the result of unemployed persons dropping out of the labor force (October was the sole exception to this of late). So, expect to see further declines in our state's Unemployment Rate in the coming months. Its effects on the $\mathrm{CCl}$ will be exactly offset by declines in the Labor Force, a feature I built into this index from the beginning.

For October, we again witnessed strength in our state's manufacturing sector. Total Manufacturing Hours rose by 2.2 percent, powered by yet another sharp increase in the length of the workweek. October was the fourth consecutive improvement in this indicator, an anomaly for Rhode Island. Along with this, the Manufacturing Wage rose again, by 3.8 percent. Benefit Exhaustions, which reflects long-term unemployment, fell sharply, dropping by 24.8 percent, its eighth consecutive improvement. But New Claims, a leading indicator that measures layoffs, rose by 4.9 percent, a potentially discouraging development. Employment Service Jobs, another leading labor market indicator, fell by 13.2 percent compared to a year ago, but its value has plateaued since June. Private Service-Producing Employment fell again $(-0.8 \%)$, its rate of decline moderating. Finally, Government Employment declined by 0.3 percent in October, fueled largely by a decrease in local non-education employment. The likely absence of any future assistance from the federal government should cause future deterioration.

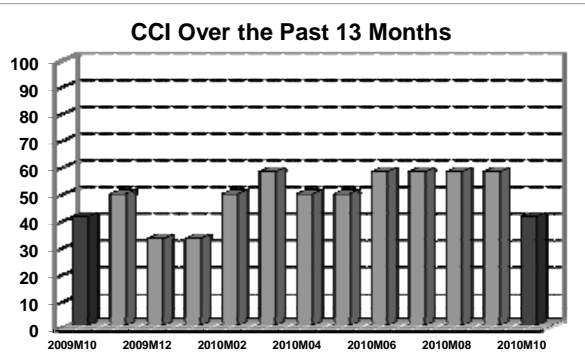

\section{THE BOTTOM LINE}

October's Current Conditions Index reading illustrates just how shallow Rhode Island's present recovery is. Our relatively slow emergence from "The Great Recession" leaves us with little margin for error. Ongoing state budget deficits, absent any further assistance from the federal government, will keep our state in a largely reactive mode and (too) highly reliant on national growth to sustain this recovery in coming months.

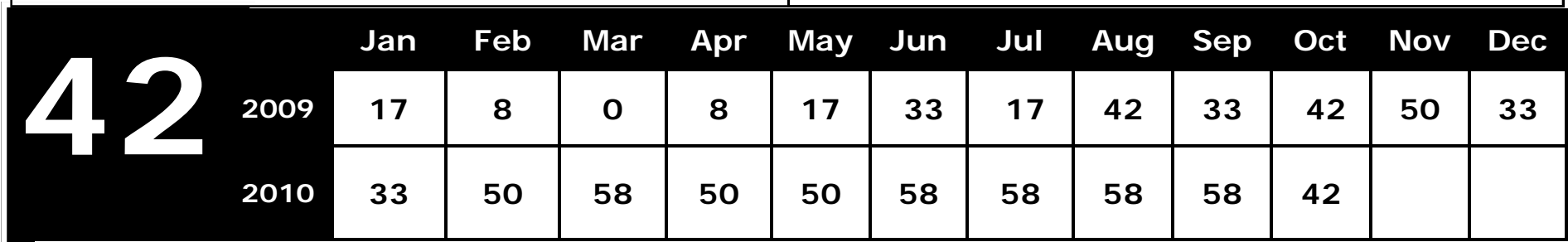

